\title{
Seroprevalensi kejadian toksoplasmosis pada kambing di UD Gading Mas Kabupaten Kediri
}

\author{
Fidi Nur Aini Eka Puji Dameanti, Mira Fatmawati, Ani Setianingrum, Ajeng Erika
}

Laboratorium Kesmavet, Fakultas Kedokteran Hewan, Universitas Brawijaya Malang

\begin{abstract}
ABSTRAK: Toksoplasmosis merupakan penyakit zoonosis prioritas berdasarkan Keputusan Menteri Pertanian Nomor 4026/Kpts/OT.140/4/2013. Salah satu penularan toksoplasmosis adalah melalui konsumsi daging kambing yang mengandung kista. Inang definitif toksoplasmosis adalah kucing, sedangkan kambing, domba dan manusia merupakan inang perantara. Rata-rata prevalensi toksoplasmosis di Jawa adalah 42,9\%. Penelitian ini bertujuan untuk mengetahui prevalensi toksoplasmosis sebagai data dasar dalam menentukan jumlah sampel penelitian lanjutan mengenai pemetaan kasus toksoplasmosis. Sampel darah diambil pada seluruh populasi kambing yang ada di UD Gading Mas Kabupaten Kediri. Pengujian IgG dan IgM pada serum kambing menggunakan Toxoplasma Modified Agglutination Test (ToMAT) di Balai Veteriner Lampung. Hasil pengujian menunjukkan bahwa prevalensi toksoplasmosis di UD Gading Mas Kabupaten Kediri adalah $\operatorname{IgG}$ positif $100 \%$ dan IgM positif $38,5 \%$.
\end{abstract}

Kata kunci:

toksoplasmosis, kambing, ToMAT, IgG, IgM.

\section{- PENDAHULUAN}

Tingkat konsumsi pangan asal hewan terutama daging kambing dan domba meningkat seiring tingginya permintaan masyarakat. Ancaman penyakit zoonosis yang berasal dari daging kambing salah satunya adalah toksoplasmosis. Toksoplasmosis seringkali dikaitkan dengan kucing, namun toksoplasmosis dapat menyerang kambing dan domba. Penularan toksoplasmosis pada manusia dilaporkan berasal dari daging kambing atau domba yang mengandung kista (Cenci-Goga et al., 2011). Penyakit ini disebabkan oleh Toksoplasma gondii. Toksoplasmosis pada kambing dan domba bersifat patogenik karena dapat menyebabkan abortus dan kematian setelah lahir pada anak. Prevalensi toksoplasmosis pada kambing dan domba di Jawa antara 7-84\% dengan rata-rata prevalensi 42,9\% (Iskandar, 2008).

UD Gading Mas merupakan sentra peternakan rakyat di Kabupaten Kediri dengan salah satu ternaknya adalah kambing. Penelitian ini melakukan pengamatan penyebaran toksoplasmosis pada kambing untuk mengetahui kejadian penyakit dan mengidentifikasi faktor resiko toksoplasmosis. Hasil penelitian ini selanjutnya digunakan untuk menentukan jumlah sampel yang akan diambil pada penelitian lanjutan tentang pemetaannya pada hewan dan manusia. Informasi terintegrasi mengenai toksoplasmosis di UD Gading Mas Kabupaten Kediri dapat menjadi informasi awal dari pilot project program pengendalian toksoplasmosis secara menyeluruh.

\section{- MATERI DAN METODE}

Sampel: Teknik pengambilan sampel adalah acak sederhana. Populasi kambing di UD Kambing Mas Kabupaten Kediri belum mengalami restrukturisasi populasi dan banyak yang bunting ( $\mathrm{N}=13$ ekor). Tempat dan waktu: Kegiatan dilaksanakan pada bulan Agustus 2018, sampel serum berasal dari kambing di UD Gading Mas Kabupaten Kediri dan pengujian serologis dilakukan di Balai Veteriner Lampung. Uji Seroprevalensi: Pengujian seroprevalensi toksoplasma menggunakan metode Toxoplasma Modified Agglutination Test (ToMAT) untuk melihat IgG dan IgM dengan prosedur pengujian sebagai berikut:

1. Preparasi sampel

Serum diencerkan menggunakan cairan PBS steril dengan perbandingan 1:20. Cairan PBS steril sebanyak $40 \mu \mathrm{L}$ dimasukan kedalam tabung mikro dan ditambahkan serum sebanyak $2 \mu \mathrm{L}$, selanjutnya disuspensi.

2. Proses pengujian sampel

Reagen uji ToMAT (merah untuk IgG dan biru untuk IgM) sebanyak $25 \mu \mathrm{L}$ dan serum sampel hasil preparasi sebanyak $25 \mu \mathrm{L}$ dimasukan kedalam sumur plat ELISA. Reagen dan larutan serum dihomogenkan dan kemudian plat ELISA ditutup dengan alumunium foil. Inkubasi dilakukan selama 20-24 jam pada suhu $4^{\circ} \mathrm{C}$. Hasil dibaca menggunakan cermin baca. Hasil negatif terlihat bulatan

Diterima: 11-03-2019 | Direvisi: 06-04-2019 | Disetujui: 10-04-2019 (C) 2019 CC-BY-SA. Ini adalah artikel Open Access yang didistribusikan berdasarkan ketentuan dari Creative Commons Attribution ShareAlike 4.0 International License (https://creativecommons.org/licenses/by-sa/4.0/). 
kecil seperti titik pada dasar lubang karena reagen ToMAT akan mengendap di dasar sumur plat ELISA

\section{口 HASIL DAN PEMBAHASAN}

Hasil interpretasi hasil positif akan terlihat reagen menyebar seperti butiran-butiran karena reagen ToMAT yang berisi takizoit berikatan dengan antibodi yang terdapat pada serum dan terjadi aglutinasi seperti pada Gambar 1 .

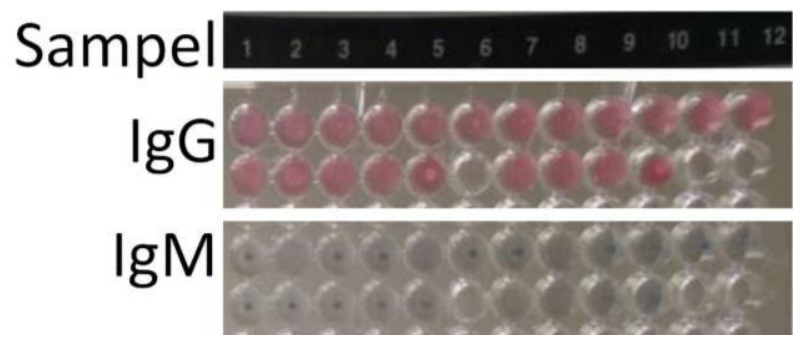

Gambar 1 Seroprevalensi toksoplasmosis dengan Metode ToMAT

Hasil pengujian seroprevalensi toksoplasmosis pada kambing di UD Gading Mas Kabupaten Kediri menunjukkan bahwa dari 13 sampel serum, 13 sampel (100\%) menunjukkan hasil positif IgG dan 5 sampel $(38,5 \%)$ menunjukkan hasil postitif IgM (Tabel 1).

Tabel 1. Seroprevalensi toksoplamosis

\begin{tabular}{|c|c|c|c|}
\hline Sampel Uji & Ig G & Ig M & Intepretasi \\
\hline 1 & + & - & Tidak \\
2 & + & + & Terinfeksi \\
3 & + & - & Tidak \\
4 & + & - & Tidak \\
5 & + & + & Terinfeksi \\
6 & + & - & Tidak \\
7 & + & - & Tidak \\
8 & + & + & Terinfeksi \\
9 & + & - & Tidak \\
10 & + & + & Terinfeksi \\
11 & + & - & Tidak \\
12 & + & + & Terinfeksi \\
13 & + & - & Tidak \\
\hline Total & 13 positif & 5 positif & Terinfeksi \\
\hline
\end{tabular}

Antibodi IgM adalah antibodi yang pertama kali timbul pada respon imun terhadap antigen dan antibodi yang utama pada golongan darah secara alami. Gabungan antigen dengan satu molekul IgM cukup untuk memulai terjadinya reaksi kaskade komplemen. Antibodi IgG mempunyai bermacam proses biologik yang dimulai dengan kompleks imun yang hasil akhirnya berupa pemusnahan antigen asing (Baratawidjaja \& Rengganis, 2009).

Infeksi oleh Toksoplasma gondii memicu munculnya sistem imun spesifik humoral dengan produk yang dihasilkan adalah IgG dan IgM. Toksoplasma akan mengaktivasi fagosit sehingga terdapat pelepasan sitokin yang mengakibatkan aktvasi sel B dan T sebagai prekrusor reaksi imun spesifik (David \& Louis, 2004). Sel B imatur mengekpresikan IgM membram di sumsum tulang selama fase perkembangan antigen independen. Sel-sel tersebut kemudian masuk kedalam sirkulasi darah dan berkembang menjadi sel B naif yang matang. Sel B naif di perifer akan mati kecuali bila terpajan dengan protein antigen larut dan diaktifkan sel $\mathrm{T}$. Sel B yang diaktifkan berproliferasi dalam organ limfoid sekunder (Ichikawa-Seki et al., 2015). Sel B dalam perkembangannya mula-mula akan memproduksi IgM atau isotipe Ig lainnya seperti IgG yang menjadi matang atau menetap sebagai sel memori. Paparan Toksoplasma mengaktivasi reseptor sel B untuk mengikat parasit darah ini sebagai antigen dan memicu proliferasi, diferensiasi menjadi sel plasma yang memproduksi antibodi, membentuk sel memori dan mempresentasikan antigen ke sel T (Baratawidjaja \& Rengganis, 2009).

\section{- SIMPULAN}

Seroprevalensi toksoplasmosis pada kambing di UD Gading Mas Kabupaten Kediri adalah 38,5 \% sehingga perlu dilakukan upaya untuk menurunkan risiko penularan.

\section{- INFORMASI PENULIS}

Penulis untuk Korespondensi

*FNAEPD: fididaemanti88@gmail.com

Laboratorium Kesmavet, Fakultas Kedokteran Hewan, Universitas Brawijaya Malang, INDONESIA

\section{- PUSTAKA ACUAN}

Baratawidjaja KG, Rengganis I. 2009. Imunologi Dasar edisi ke8. Fakultas Kedokteran Universitas Indonesia, Jakarta. hal 27-40.

Cenci-Goga BT, Rossitto PV, Sechi P, McCrindle CME, Cullor JS. 2011 Toksoplasma in Animals, Food, and Humans: An Old Parasite of New Concern. Foodborne Pathogens and Disease. 8(7): 751-762.

David S, Louis MW. 2004. World Class Parasite: Volume 9. Opportunistic Infections: Toxoplasma, Sarcocytis, and Mycrosporidia. Kluwer Academic Publisher.

Ichikawa-Seki M, Guswanto A, Allamanda P, Mariamah ES, Wibowo PE, Igarashi I, Nishikawa Y. 2015. Seroprevalence of antibody to TgGRA7 antigen of Toksoplasma gondii in livestock animals from Western Java, Indonesia. Parasitology International, 64(6): 484-486.

Iskandar T. 2008. Penyakit Toksoplasmosis pada Kambing dan Domba di Jawa. Wartazoa. 18(3):157-66. 